\title{
15 YEARS OF PARAGANGLIOMA Clinical manifestations of paraganglioma syndromes types 1-5
}

\section{Diana E Benn, Bruce G Robinson and Roderick J Clifton-Bligh}

Cancer Genetics, Kolling Institute, Royal North Shore Hospital, University of Sydney, St Leonards, New South Wales 2065, Australia
Correspondence should be addressed to R J Clifton-Bligh Email jclifton@med.usyd.edu.au

\begin{abstract}
The paraganglioma (PGL) syndromes types 1-5 are autosomal dominant disorders characterized by familial predisposition to PGLs, phaeochromocytomas (PCs), renal cell cancers, gastrointestinal stromal tumours and, rarely, pituitary adenomas. Each syndrome is associated with mutation in a gene encoding a particular subunit (or assembly factor) of succinate dehydrogenase $(S D H x)$. The clinical manifestations of these syndromes are protean: patients may present with features of catecholamine excess (including the classic triad of headache, sweating and palpitations), or with symptoms from local tumour mass, or increasingly as an incidental finding on imaging performed for some other purpose. As genetic testing for these syndromes becomes more widespread, presymptomatic diagnosis is also possible, although penetrance of disease in these syndromes is highly variable and tumour development does not clearly follow a predetermined pattern. PGL1 syndrome (SDHD) and PGL2 syndrome (SDHAF2) are notable for high frequency of multifocal tumour development and for parent-of-origin inheritance: disease is almost only ever manifest in subjects inheriting the defective allele from their father. PGL4 syndrome (SDHB) is notable for an increased risk of malignant PGL or PC. PGL3 syndrome (SDHC) and PGL5 syndrome (SDHA) are less common and appear to be associated with lower penetrance of tumour development. Although these syndromes are all associated with SDH deficiency, few genotype-phenotype relationships have yet been established, and indeed it is remarkable that such divergent phenotypes can arise from disruption of a common molecular pathway. This article reviews the clinical presentations of these syndromes, including their component tumours and underlying genetic basis.
\end{abstract}
Key Words
- paraganglioma
- phaeochromocytoma
- renal cancer
- gastrointestinal stromal tumour
- succinate dehydrogenase

Endocrine-Related Cancer (2015) 22, T91-T103

\section{Introduction}

Phaeochromocytomas (PCs) are tumours in the adrenal medulla, and paragangliomas (PGLs) arise in extra-adrenal sympathetic chromaffin tissue or head and neck parasympathetic tissues. Familial occurrence of PGLs was first reported in 1933 by Chase (1933), and co-occurrence of PCs and PGLs (collectively termed PPGLs) in some families was recognised somewhat later (Pritchett 1982, Jensen et al. 1991). The genetic basis for hereditary PGL syndrome type 1 (PGL1) was discovered by Baysal et al. (2000) by combining knowledge that hypoxia increases the risk of carotid body PGLs with the presence of a hypoxiaresponsive gene encoding succinate dehydrogenase 
subunit D $(S D H D)$ within a region at chromosome 11q23 linked in family studies to hereditary head and neck PGLs (HNPGLs). The phenotype of germline SDHD mutations was quickly extended to include thoracoabdominal PGLs (TAPGLs) and PCs (Gimm et al. 2000, Astuti et al. 2001a). Soon thereafter, the SDHC gene was found to be mutated in familial HNPGLs (PGL3; Niemann $\&$ Muller 2000) and $S D H B$ mutations were discovered in familial PPGLs (PGL4; Astuti et al. 2001b). SDHAF2, required for flavination of SDHA, is mutated in the rare PGL2 (Hao et al. 2009), and PGL5 is associated with mutations in SDHA (Burnichon et al. 2010).

Germline mutations in predisposition genes are now found in 25-30\% of PPGLs overall (Gimenez-Roqueplo et al. 2012). Germline mutations in $S D H x$ genes are the commonest genetic cause of PPGLs, occurring in up to $25 \%$ cases (Baysal et al. 2002, Neumann et al. 2002). By comparison the next most commonly associated genes are von HippelLindau (VHL) (4-10\%), RET (1-5\%) and NF1 (1-5\%).

$\mathrm{SDH}$ is located on the inner mitochondrial membrane and functions in the mitochondrial respiratory chain and the Krebs cycle. In the respiratory chain, SDH transports electrons to the ubiquinone pool, then to cytochrome $c$ of complex III. In the Krebs cycle, SDH catalyses conversion of succinate to fumarate. Therefore, two predictable consequences of SDH inactivation are succinate accumulation and increased production of reactive oxygen species. Both outcomes have been suggested to contribute to cellular accumulation of hypoxia-inducible factors (Selak et al. 2005), and tumours associated with SDH deficiency display notable upregulation of hypoxiaresponsive genes. Notably, this gene expression signature is shared by PPGLs associated with mutations in VHL (Dahia et al. 2005).

In this article, we review the clinical manifestations of PGL1-5. We begin by considering the approach to the patient and then discuss each syndrome in turn, including genotype-phenotype interrelationships, before a detailed overview of each component tumour type. We finish with a proposed clinical management approach. A summary of clinical features of each syndrome is shown in Table 1, and a synoptic view of PGL-associated tumours is shown in Fig. 1.

\section{Cardinal manifestations of PGL1-5}

PGL1-5 are characterised by the development of PGLs and/or PCs, together with a variable risk of developing renal cancers, gastrointestinal stromal tumours (GISTs) or (rarely) pituitary tumours. The patient with a PGL syndrome will therefore present in one of four ways: i) with symptoms and/or signs of catecholamine excess; ii) with symptoms and/or signs of local tumour mass; iii) as an incidental finding on an imaging study for unrelated purpose and iv) after genetic testing in context of familial disease.

Clinical features of catecholamine excess include hypertension, headache, sweating, palpitations, and often morbid apprehension or anxiety. These symptoms often come in paroxysms that can last for minutes or hours, with variable frequency. Clinical examination may reveal hypertension (although absent in 10-20\% cases, and paroxysmal in 30\%), pallor, hyperhidrosis and tremor (Plouin et al. 1981).

Rarely, patients may present with catecholaminergic 'crisis' accompanied by acute cardiomyopathy and severe hypertension (but sometimes with shock), and/or multiorgan failure, lactic acidosis, encephalopathy, fever and hyperglycaemia (Amar \& Eisenhofer 2015). In such cases, precipitating factors may be present including recent use of dopamine D2 agonists (e.g. metoclopramide), corticosteroids, $\beta$-blockers or anaesthesia.

PGL of the urinary bladder is associated with catcholaminergic symptoms that are provoked by micturition, and may also be associated with painless haematuria (Beilan et al. 2013).

Clinical features of local tumour mass are relevant for HNPGLs and also for metastatic PPGLs. Carotid body

Table 1 Clinical features (penetrance) of PGL syndromes 1-5

\begin{tabular}{|c|c|c|c|}
\hline Syndrome & Gene & PC & TAPGL \\
\hline PGL1 & $S D H D^{a}$ & $\sim 10-25 \%$ & $20-25 \%$ \\
\hline PGL2 & $S D H A F 2^{a}$ & 0 & 0 \\
\hline PGL3 & $S D H C$ & 0 & Rare \\
\hline PGL4 & $S D H B$ & $20-25 \%$ & $50 \%$ \\
\hline PGL5 & SDHA & Rare & Rare \\
\hline
\end{tabular}

\begin{tabular}{l} 
HNPGL \\
\hline $85 \%$ \\
$100 \%$ \\
$?^{b}$ \\
$20-30 \%$ \\
Rare
\end{tabular}

\begin{tabular}{l} 
Multifocal \\
\hline $55-60 \%$ \\
0 \\
$15-20 \%$ \\
$20-25 \%$ \\
Rare
\end{tabular}

\begin{tabular}{l} 
Malignant \\
\hline$\sim 4 \%$ \\
0 \\
$0 \%$ \\
$\sim 30 \%$ \\
Rare
\end{tabular}

\begin{tabular}{l} 
RCC \\
\hline$\sim 8 \%$ \\
0 \\
Rare \\
$\sim 14 \%$ \\
0
\end{tabular}

\begin{tabular}{l} 
Other \\
\hline GIST and PA \\
- \\
GIST \\
GIST and PA \\
GIST and PA
\end{tabular}

PC, phaeochromocytoma; TAPGL, thoracoabdominal PGL; HNPGL, head and neck PGL; RCC, renal cell carcinoma; PA, pituitary adenoma; GIST, gastrointestinal stromal tumour. Neumann et al. (2002), Amar et al. (2005), Schiavi et al. (2005), Benn et al. (2006), Cascón et al. (2009), Hao et al. (2009), Mannelli et al. (2009), Burnichon et al. (2009), Ricketts et al. (2010), Welander et al. (2011) and Gimenez-Roqueplo et al. (2012).

apaternally inherited.

bLifetime prevalence not yet determined.

http://erc.endocrinology-journals.org DOI: 10.1530/ERC-15-0268
(C) 2015 The authors Printed in Great Britain
Published by Bioscientifica Ltd 
UNCOMMON

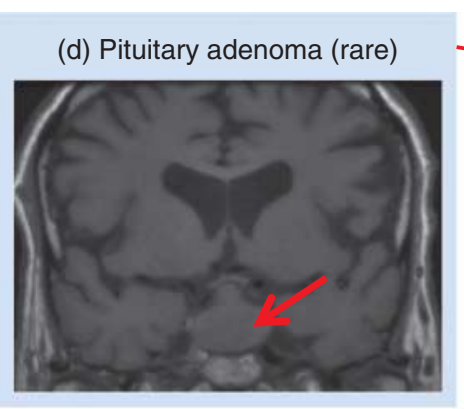

(e) Renal cell carcinoma

(f) GIST

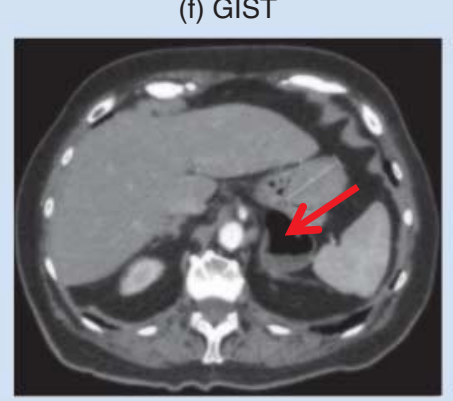

\section{Figure 1}

Tumour types associated with paraganglioma syndromes $1-5$. In each panel the tumour is arrowed and is: (A) a left-sided carotid body paraganglioma (the scar from previous surgery for a right carotid body PGL is faintly

tumours and vagal PGLs may present with neck fullness, cough, hoarse voice, or dysphagia and are clinically palpable in the lateral upper neck (Fig. 1). Glomus tympanicum tumours may present with unilateral hearing loss and/or pulsatile tinnitus. Jugular PGLs may present with palsies of lower cranial nerves VII, IX, X, XI and/or XII (Suárez et al. 2013). Local symptoms from tumour mass also occur with renal cell cancers that can present with flank pain and/or haematuria, and GISTs that may present with abdominal pain and/or gastrointestinal bleeding. Pituitary tumours are rarely associated with hereditary PGLs and present with features either of local tumour mass (headache, visual field deficit) and/or hormonal excess (acromegaly, hyperprolactinaemia; Xekouki et al. 2015).

Incidental discovery of PPGLs on imaging is becoming an increasingly important mode of their diagnosis; for instance, the proportion of PCs detected incidentally is now 25-30\% of all cases (Mannelli et al. 1999, Amar et al. 2005, Kopetschke et al. 2009, Shen et al. 2010). Specific imaging findings are discussed in more detail below. visible); (B) a left-sided phaeochromocytoma; (C) abdominal PGL (not shown); (D) a pituitary macroadenoma; (E) renal cell carcinoma (not shown), and (F) a gastrointestinal stromal tumour.

A detailed family history is essential, including known history of PPGLs, renal cancer, GISTs and/or unexplained sudden death.

\section{The PGL syndromes 1-5}

Some general points can be made about these syndromes: i) they are autosomal dominant disorders, with maternal imprinting effects for $S D H D$ and $S D H A F 2$; ii) the penetrance of tumour development in subjects carrying $S D H x$ mutations is highly variable, in particular for PGL3-5 highlighted by the occasional finding that a child or young adult is the index case in a family where the parent (and sometimes grandparent) carrying the pathogenic allele has not developed tumours and iii) tumour development does not clearly follow a predetermined pattern - PPGLs, renal cancer, GISTs and/or pituitary tumours occur in a seemingly random fashion in affected subjects.

Published by Bioscientifica Ltd. 


\section{PGL1: SDHD}

SDHD is maternally imprinted, with the result that the disease almost only ever occurs with paternally inherited mutations (Taschner et al. 2001, Neumann \& Erlic 2008, Pigny et al. 2008, Yeap et al. 2011) and as such, to the uninitiated, may appear to 'skip' generations. When paternally inherited, SDHD mutations are associated with frequent development of HNPGL and less commonly TAPGLs or phaechromocytomas (Neumann et al. 2004, Schiavi et al. 2005, Benn et al. 2006, Ricketts et al. 2010). PGL1 has very high lifetime penetrance, and $75 \%$ of carriers will manifest disease by age 40 (Benn et al. 2006). PGL1 demonstrates multifocal tumour development in around 56\% cases, although malignancy is infrequent (Neumann et al. 2004, Schiavi et al. 2005, Benn et al. 2006, Ricketts et al. 2010). Renal cancers are found in $8 \%$
(Ricketts et al. 2010). Pituitary adenomas have been reported in a few cases of PGL1 (Xekouki et al. 2012, Evenepoel et al. 2014).

More than 130 unique DNA mutations have been reported in PGL1 (Fig. 2). These mutations are evenly distributed across the four coding exons. Prematurely truncating mutations (by frameshift or nonsense variants) are particularly common in $S D H D$, and one study found that these mutations were associated with a significantly increased risk of phaeochromocytoma or sympathetic PGL compared to missense mutations that were not predicted to impair protein stability (Ricketts et al. 2010).

\section{PGL2: SDHAF2}

PGL2 was initially described in a Dutch family (van Baars et al. 1982), and associated with SDHAF2 in 2009 (Hao et al. 2009).
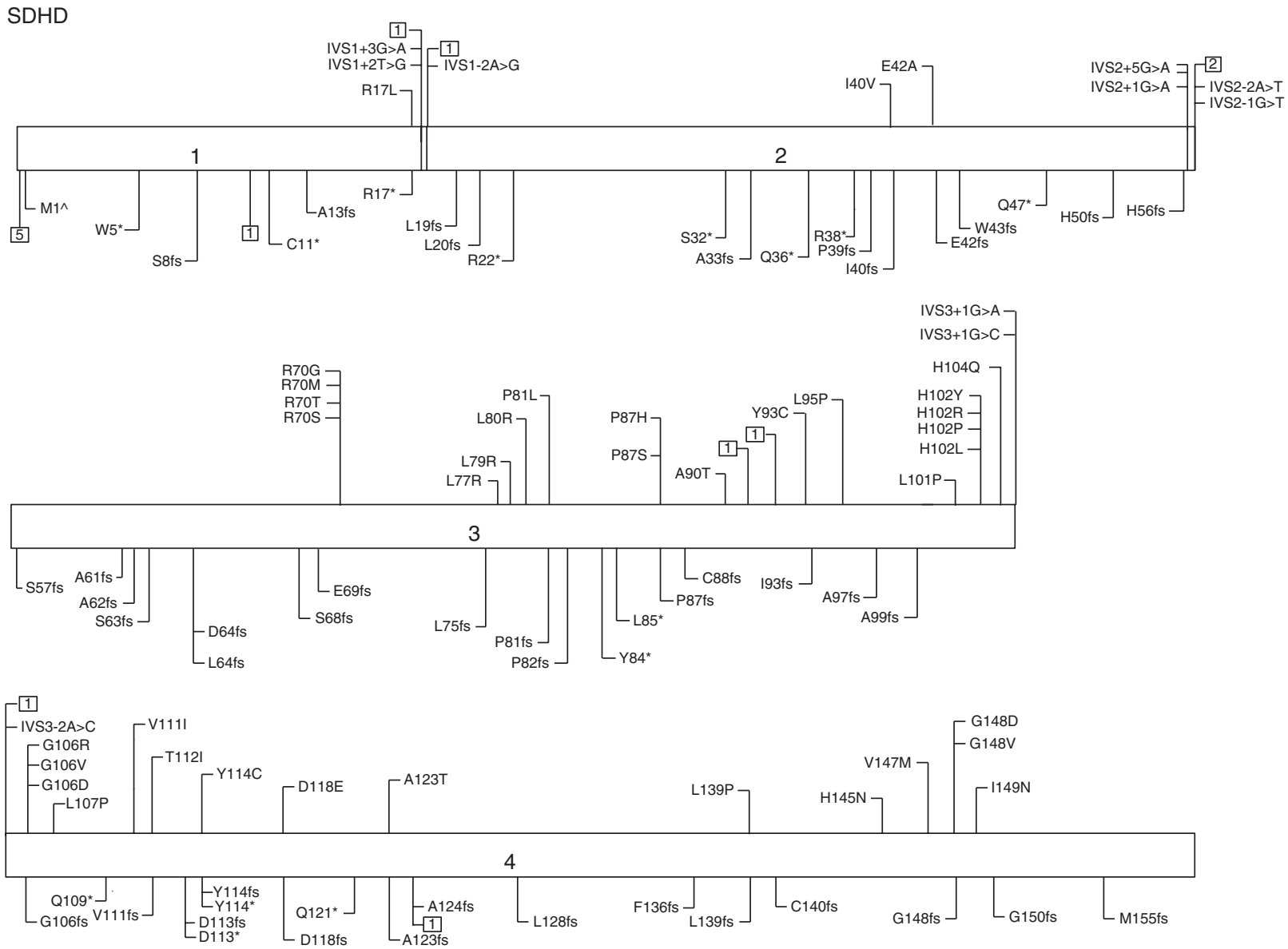

Figure 2

PGL1 due to mutations in SDHD. Genotypes associated with paraganglioma syndromes. Mutations are not represented by standard nomenclature; abbreviations are used for representation purposes only. Not all mutations identified worldwide have been included. $\mathrm{M}^{\wedge}{ }^{\wedge}$, mutation in initiator methionine indicating loss of transcript; *, represent stop codons; $\square \square$, represent a large deletion/insertion/duplication and the number indicates the number of different mutations at that site. Data from http://chromium. lovd.nl/lovd_sdh, Bayley et al. (2005), McWhinney et al. (2004). 


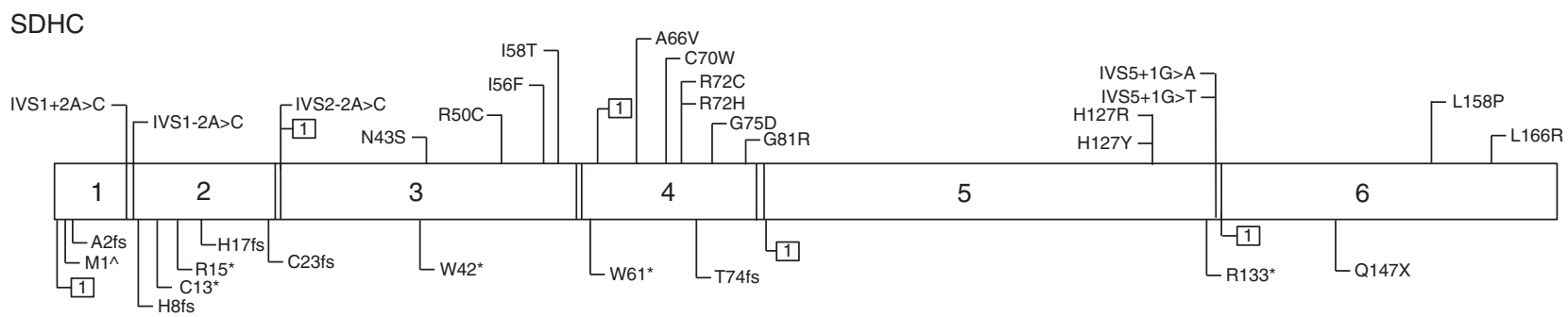

\section{Figure 3}

PGL3 due to SDHC mutations. Genotypes associated with paraganglioma syndromes. Mutations are not represented by standard nomenclature; abbreviations are used for representation purposes only. Not all mutations identified worldwide have been included. $\mathrm{M}^{\wedge}{ }^{\wedge}$, mutation in initiator

SDHAF2 mutations are a rare cause of PPGLs: only four PGL2 families have been described. SDHAF2 is encoded by four exons located at chromosome $11 \mathrm{q} 13$ and, like $S D H D$, is maternally imprinted. HNPGLs occur in 75\% carriers of paternally inherited mutations, starting from relatively young age (earliest affected aged 22 years) and often multifocal but are not malignant (Kunst et al. 2011). Neither TAPGLs nor PCs have yet been reported in PGL2.

\section{PGL3: SDHC}

Mutations in SDHC have been identified in patients with HNPGL and, rarely, TAPGLs and PCs (Schiavi et al. 2005). Linkage analyses of large families revealed this third locus for hereditary PGL, termed PGL3 (Niemann \& Muller 2000, Niemann et al. 2003, Muller et al. 2005). Overall, germline SDHC mutations are found in around $4 \%$ of HNPGL (Schiavi et al. 2005) but very few functioning PPGLs (Mannelli et al. 2007, Peczkowska et al. 2008). Patients with SDHC mutations are more likely to develop carotid body tumours, less likely to have multiple tumours than in SDHD mutated PGL, and have low malignant potential compared to $S D H B$-mutated PGL (Schiavi et al. 2005).

Nearly 50 unique SDHC mutations have been described in PGL3 to date, and these are evenly distributed between the six coding exons (Fig. 3).

\section{PGL4: SDHB}

SDHB mutations were first found to be associated with PPGL in 2001 (Astuti et al. 2001b, Gimenez-Roqueplo et al. 2001). In comparison to PGL1, patients with $S D H B$ mutations have lower penetrance for disease and may present with unifocal disease at a later age, with perhaps only about $40 \%$ of carriers manifesting the disease by age methionine indicating loss of transcript; *, represent stop codons; $\square \square$, represent a large deletion/insertion/duplication and the number indicates the number of different mutations at that site. Data from http://chromium. lovd.nl/lovd_sdh, Bayley et al. (2005).

40 (Schiavi et al. 2010). However, PGL4 is more likely to be associated with TAPGL and/or PC, is more likely to present with symptoms from local tumour mass, and malignant disease occurs in around a third of patients (Benn et al. 2003, Gimenez-Roqueplo et al. 2003, Brouwers et al. 2006, Amar et al. 2007, Timmers et al. 2007). HNPGL occurs in $20-30 \%$, renal cell cancer in about $14 \%$ and GISTs in $2 \%$ of carriers of pathogenic SDHB mutations (Benn et al. 2006, Ricketts et al. 2010).

More than 200 unique $S D H B$ mutations occurring in all its eight coding exons have been described in PGL4; there are interesting clusters of mutations at the junction of exons 3/4 and in exons 6 and 7 that appear to occur within iron-sulfur cluster domains of SDHB (Fig. 4).

\section{PGL5: SDHA}

Mutations in SDHA were originally described as a cause of autosomal recessive juvenile encephalopathy (Leigh syndrome; Bourgeron et al. 1995). In 2010, a heterogygous SDHA germline mutation was identified in a 32-year-old woman with abdominal PGL (Burnichon et al. 2010). SDHA mutations remain a rare cause of PPGL, accounting for about 3\% of cases and with low penetrance such that familial disease is uncommon (Korpershoek et al. 2011). GISTs and pituitary adenomas may also be the presenting features of PGL5 (Dwight et al. 2013a,b).

Genetic testing for $S D H A$ mutations is complicated by the presence of three pseudogenes - SDHAP1 (localized to 3q29), SDHAP2 (3q29) and SDHAP3 (5p15.33) - which are highly homologous to not only the coding regions of SDHA but also the intronic regions of the gene. SDHA is also the largest SDHx gene, with 15 exons (Fig. 5). Fortunately, SDHA immunohistochemistry has proved useful in identifying tumours that are likely to contain SDHA mutations (Burnichon et al. 2010).

Published by Bioscientifica Ltd 

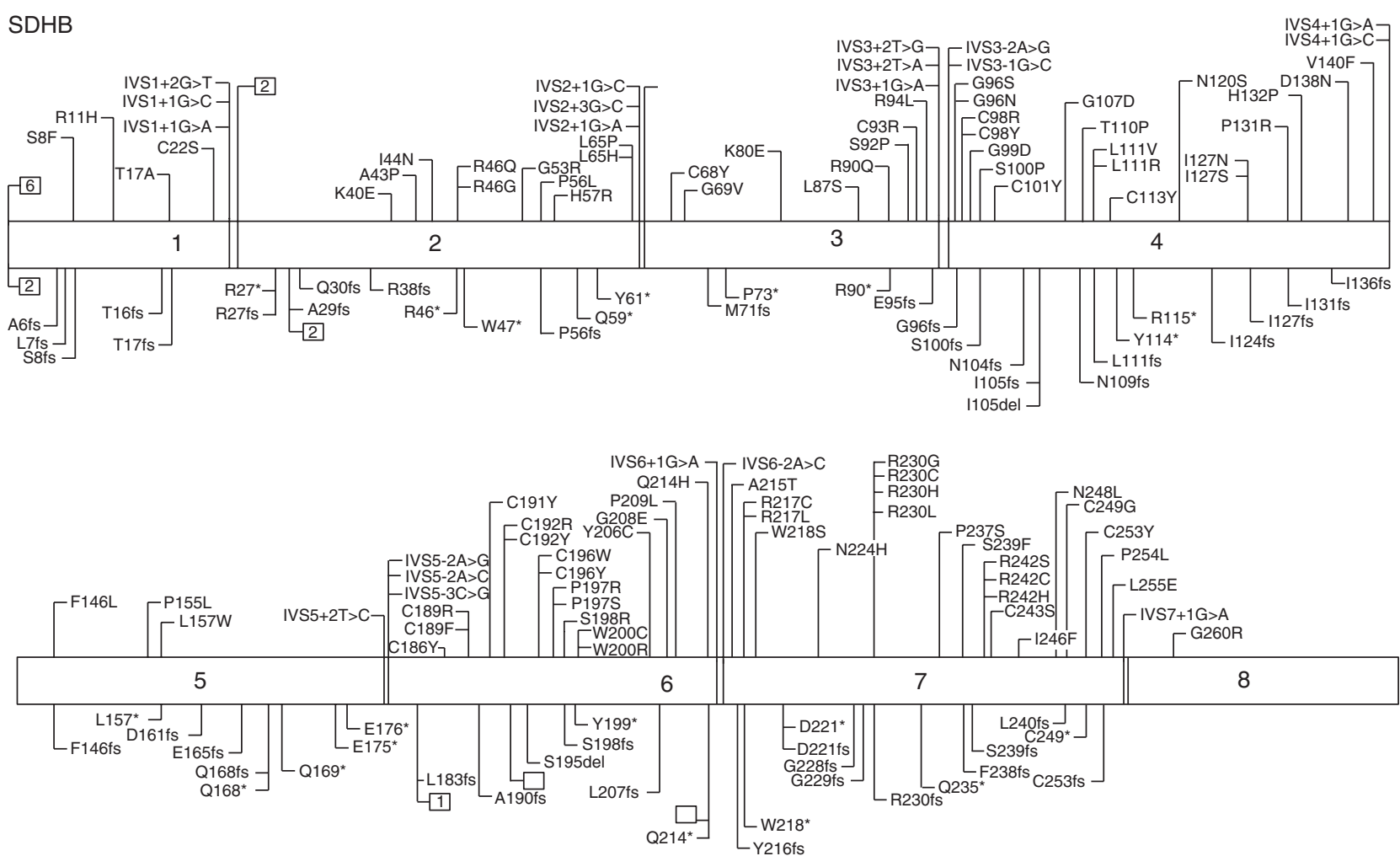

Figure 4

PGL4 due to SDHB mutations. Genotypes associated with paraganglioma syndromes. Mutations are not represented by standard nomenclature; abbreviations are used for representation purposes only. Not all mutations identified worldwide have been included. $\mathrm{M}^{\wedge}{ }^{\wedge}$, mutation in initiator

\section{Tumours associated with PGL1-5}

\section{Paragangliomas}

These tumours arise from the neuroendocrine paraganglia that occur along the paravertebral axis from the base of the skull through to the pelvis (Fig. 1), and are divided into those that derive from the parasympathetic paraganglia (HNPGLs) or those from sympathetic paraganglia (TAPGLs). Approximately 40\% of all PGLs are associated with SDH deficiency (Gill et al. 2010a), and those associated with $S D H B$ mutations (PGL4) are at higher risk of malignancy (Timmers et al. 2007).

HNPGLs associated with PGL syndromes include carotid body PGLs located at the carotid bifurcation, glomus vagale tumours located along the vagus nerve and glomus jugulare tumours located in the jugular foramen (Gimenez-Roqueplo et al. 2013, Taïeb et al. 2014). Rarer locations for HNPGLs include glomus tympanicum tumours within the middle ear and PGLs of the larynx, nasopharynx, orbit, tongue and thyroid (Taïeb et al. 2014). methionine indicating loss of transcript; *, represent stop codons; $\square \square$, represent a large deletion/insertion/duplication and the number indicates the number of different mutations at that site. Data from http://chromium.lovd. nl/lovd_sdh, McWhinney et al. (2004), Bayley et al. (2005), Cascón et al. (2006).

HNPGLs are usually non-secreting: only about 5\% are associated with elevated plasma or urine normetanephrine, although $30 \%$ are associated with elevated dopamine metabolite 3-methoxytyramine (van Duinen et al. 2010, Eisenhofer et al. 2012). HNPGLs are also less likely to be malignant ( $<5 \%$; Taïeb et al. 2014). Living at high altitude may promote the development of HNPGLs in PGL1 (Astrom et al. 2003); whether altitude is a phenotypic modifier in other PGL syndromes has not been established. HNPGLs may be discovered as an incidental finding on imaging studies. Magnetic resonance imaging (MRI) is typically the best modality for detailed imaging of HNPGLs, demonstrating low T1-signal and intermediatehigh signal on T2-weighted images and intense enhancement after gadolinium contrast; on computed tomography (CT) imaging, intratumoral blood vessels are strongly enhanced after contrast (Taïeb et al. 2014).

TAPGLs arise from chromaffin tissue in sympathetic ganglia in the abdomen, less commonly in the pelvis (including urinary bladder) and rarely in the mediastinum

Published by Bioscientifica Ltd. 

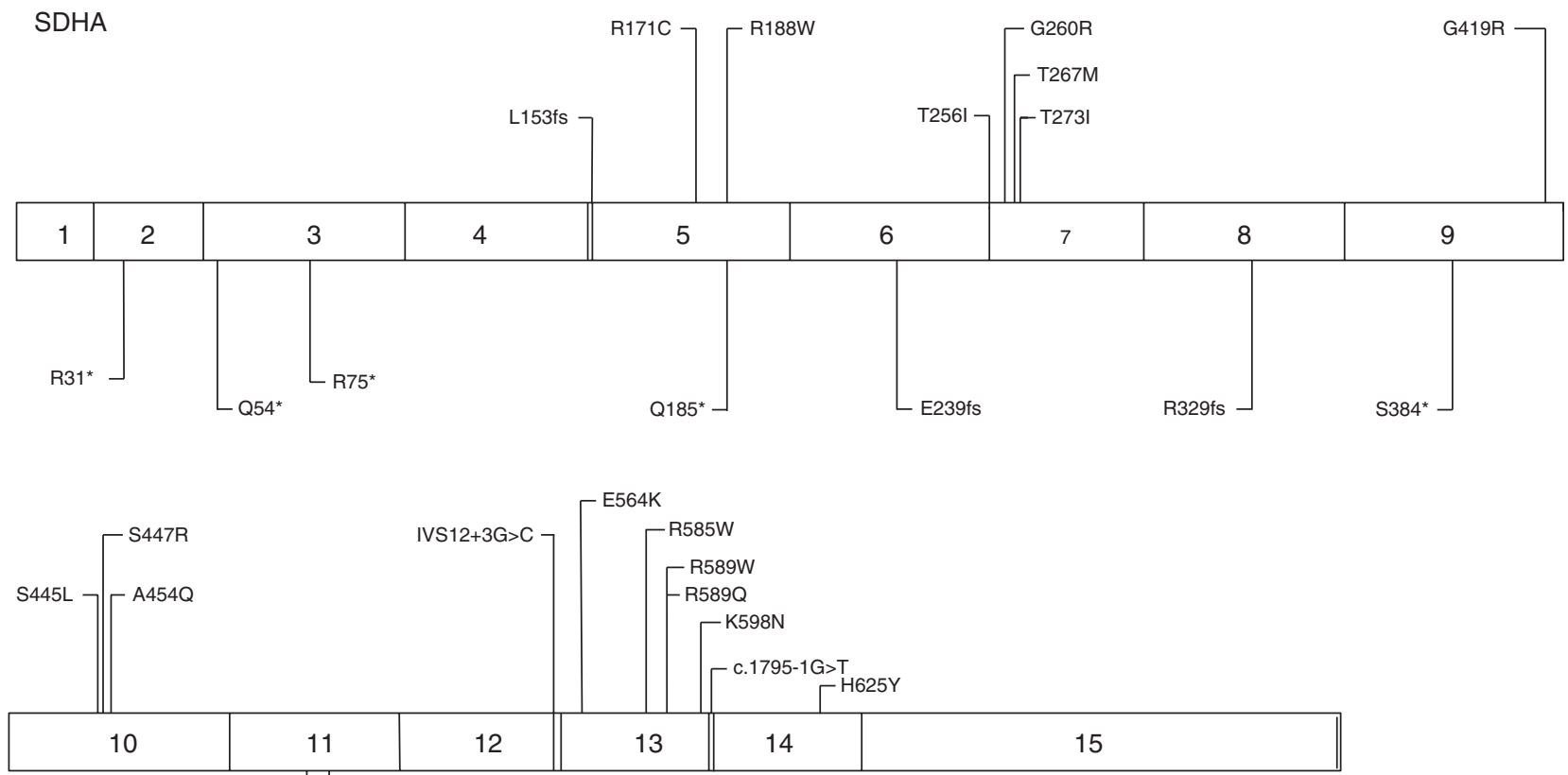

\section{Figure 5}

PGL5 due to SDHA mutations. Genotypes associated with paraganglioma syndromes. Mutations are not represented by standard nomenclature; abbreviations are used for representation purposes only. Not all mutations identified worldwide have been included. $\mathrm{M}^{\wedge}{ }^{\wedge}$, mutation in initiator

(Young 2006). Within the abdomen, a common location is the organ of Zuckerkandl at the origin of the inferior mesenteric artery. TAPGLs display broadly similar imaging characteristics to PCs on CT and MRI. More recently, ${ }^{68} \mathrm{Ga}$-DOTATATE positron emission tomography (PET)/CT has shown great promise in imaging both primary and metastatic TAPGLs (Maurice et al. 2012). In a series of 17 subjects with SDHB-related metastatic PGLs, DOTATATE PET identified $98.6 \%$ metastatic lesions compared to $85.8 \%$ for FDG-PET (Janssen et al. 2015). A PGL1 case history illustrating the utility of ${ }^{68} \mathrm{Ga}$-DOTATATE scanning is shown in Fig. 6.

\section{Phaeochromocytomas}

These are catecholamine-secreting PGLs confined to the adrenal medulla. Approximately $3 \%$ of all PCs are associated with SDH deficiency (Gill et al. 2010b) and occur as part of PGL1 and PGL4; except for negative SDHB immunohistochemistry (discussed in detail below), these are otherwise histologically indistinguishable from sporadic PCs or from PCs associated with other heritable syndromes (e.g. multiple methionine indicating loss of transcript; *, represent stop codons; $\square \square$, represent a large deletion/insertion/duplication and the number indicates the number of different mutations at that site. Data from http://chromium. lovd.nl/lovd_sdh, Bayley et al. (2005).

endocrine neoplasia type 2 (MEN2), VHL and NF). PCs that occur in PGL1 and PGL4 secrete only noradrenaline (and/or dopamine), in contrast to PCs associated with MEN2, NF1 or MAX from which mixed adrenaline and noradrenaline secretion occurs. PCs associated with $S D H B$ mutations (PGL4) show a higher risk of malignancy.

PCs are usually easily visible $(\geq 3 \mathrm{~cm})$ on abdominal CT at time of presentation and are typically dense $(\geq 10$ Hounsfield units), but may be heterogeneous, with areas of low density. On MRI, PCs are classically isointense with respect to the liver on T1-weighted images and hyperintense on T2-weighted images (Jacques et al. 2008).

Nuclear medicine imaging with MIBG or PET may also be useful for diagnosis of PC in adrenal lesions with equivocal biochemical testing. MIBG is less sensitive in smaller adrenal lesions such that tumors $<2.5 \mathrm{~cm}$ are likely to be negative (Bhatia et al. 2008). Standard ${ }^{18} \mathrm{~F}$ FDG-PET imaging was reported to have $88 \%$ sensitivity in diagnosis of non-metastatic PC/PGL (Timmers et al. 2009), although this series included a relatively large number of tumors containing $S D H B$ mutations (which are more likely to be positive due to altered glucose transport). Other PET

Published by Bioscientifica Ltd 


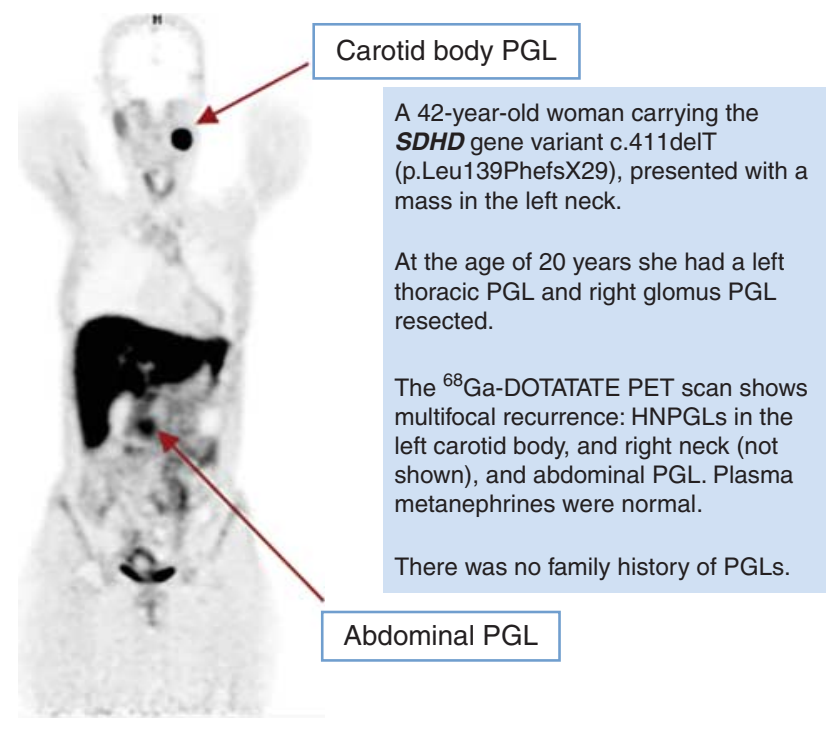

Figure 6

A representative clinical vignette of PGL syndrome type 1 .

tracers such as ${ }^{18} \mathrm{~F}-\mathrm{DOPA}$ (Hoegerle et al. 2002) and ${ }^{18}$ F-FDA (Pacak et al. 2001) have shown utility in PPGL diagnosis and these may be more useful than MIBG in assessment of smaller adrenal lesions. As discussed above for HNPGLs and TAPGLs, ${ }^{68}$ Ga-DOTATATE PET imaging may also be useful for diagnosis of PC (although the normal adrenal medulla does take up this tracer) and/or metastatic disease.

\section{Renal cell cancer}

Renal carcinoma occurs in $\sim 14 \%$ of PGL4 (Vanharanta et al. 2004, Ricketts et al. 2008, Gill et al. 2011) and 8\% of PGL1; one case with SDHC mutation has been reported, and none with SDHA or SDHAF2 (Gill et al. 2013). It may be the index tumour in PGL1 or PGL4, presenting at mean age of 37 years (range 14-76), and indeed in many cases it is the sole tumour: two-thirds of patients with SDH-deficient renal cancers had not developed metachronous PPGLs or GISTs by time of report, although many of these patients were still at relatively young age (Gill et al. 2014a, Paik et al. 2014). Bilateral renal cancers occur in $26 \%$ of SDH-deficient cases, and metastases occur in 33\% of the cases. Although only $0.05-0.2 \%$ of all renal cancers are associated with SDHx mutations, they can be recognised by distinct pathological features including solid or focally cystic growth, uniform cytology with eosinophilic flocculent cytoplasm, intracytoplasmic vacuolations and inclusions and round-to-oval low-grade nuclei. In $S D H B$ mutated renal cancers, immunohistochemistry for SDHB is negative. Although no clear-cut genotype-phenotype correlations have been defined, it is interesting to note that four unrelated subjects who developed renal cancer all harboured the same $S D H B$ splice site mutation (c. $423+$ $1 G>A)$, and that two of these subjects developed multifocal disease (Gill et al. 2014a). Further work is required to determine whether this mutation is specifically associated with risk of developing renal cancer.

\section{Gastrointestinal stromal tumours}

GISTs are the commonest mesenchymal tumor of the gastrointestinal tract, and most are driven by somatic activating mutations of KIT (75-80\%) or PDGFRA (5-8\%) (Corless et al. 2011). GISTs associated with hereditary PGL syndromes are usually detected by negative immunohistochemistry for SDHB (see below). However, only 50\% of such SDH-deficient GISTs are found to be associated with germline mutations in an SDHx gene: 30\% due to $S D H A$ mutations, and 10-20\% due to mutations in SDHB, SDHC or SDHD (Gill et al. 2010a). SDH-deficient GISTs occur exclusively in the stomach, commonly metastasise to lymph nodes, have a propensity to multifocal or metachronous disease, commonly show primary resistance to imatinib and demonstrate a tendency to relatively indolent behavior of metastases (Gill et al. 2010a). GISTs associated with hereditary PGL due to germline mutations of $S D H A$, $S D H B, S D H C$ or SDHD are known as the Carney-Stratakis syndrome (Pasini et al. 2008, Janeway et al. 2011, Pantaleo et al. 2011a,b). GISTs also occur as part of the Carney triad: the syndromic but non-hereditary association of SDHdeficient GISTs now known to be associated with hypermethylation of the SDHC promoter (Haller et al. 2014, Killian et al. 2014).

\section{Pituitary tumours}

An aetiopathological link between SDHx mutations and pituitary tumours is strongly suggested by case reports of pituitary tumours that demonstrate loss of SDHB immunostaining, occurring in patients who carry germline mutations in SDHA (Dwight et al. 2013b, Papathomas et al. 2013), SDHB (Xekouki et al. 2015), SDHC (LopezJimenez et al. 2008) and SDHD (Xekouki et al. 2012). Nevertheless, pituitary adenomas are very uncommon in PGL syndromes (Xekouki \& Stratakis 2012), and conversely $<0.3 \%$ of all pituitary tumours are associated with SDH deficiency (Gill et al. 2014b). Based on the small number of reports available, SDHx mutation-associated pituitary tumours are more commonly macroadenomas

Published by Bioscientifica Ltd. 
secreting either growth hormone or prolactin, and display a more aggressive phenotype (Xekouki et al. 2015).

\section{Thyroid carcinoma}

A few individuals with an $S D H B$ or an SDHD pathogenic variant have had thyroid carcinoma (Neumann et al. 2004, Ricketts et al. 2010). The association is generally regarded to be casual between a common disease (thyroid cancer) and a rare one (PPGL).

\section{Negative immunohistochemistry for SDHB is a surrogate marker for SDH deficiency and provides functional validation of pathogenic SDHx mutations}

SDHx are tumour suppressor genes: inheritance of a pathogenic mutation on one allele in the germline is typically accompanied by loss of the normal allele in tumours (Gimenez-Roqueplo et al. 2001). Loss of SDHB immunostaining has proved to be an important tool for recognising tumours associated with mutations in any of the SDHx genes, and indeed is a robust assay in all the multiple tumour types described above. In a large multicenter study, 62 of 69 PPGLs associated with mutations in $S D H B / C / D / A F 2$ were negative for SDHB immunohistochemistry, whereas two SDHD-mutated tumours were scored as immunopositive (Papathomas et al. 2015). About 16\% of VHLmutated PPGLs also show loss of SDHB staining (Papathomas et al. 2015). Tumors associated with mutations in $R E T$ or $N F 1$, on the other hand, usually show positive granular SDHB cytoplasmic staining (consistent with normal mitochondrial location of SDH; van Nederveen et al. 2009, Gill et al. 2010b). Immunohistochemistry for SDHA has also been used to identify tumors associated with germline mutations in that gene (Burnichon et al. 2010, Korpershoek et al. 2011, Papathomas et al. 2015).

Extended experience suggests that $<10 \%$ of PC/PGLs are SDHB negative by immunohistochemistry but are not associated with identifiable $S D H x$ mutations (Papathomas et al. 2015), raising the possibility that other mechanisms of mitochondrial complex 2 instability exist which lead to tumorigenesis. As noted above, this phenomenon is more common in GISTs.

\section{Genetic counseling/testing}

Despite high heritability, the approach to genetic testing in patients presenting with PPGLs remains controversial, acknowledged in recent guidelines that recommend the use of a clinical feature-driven diagnostic algorithm to guide specific genetic testing (Lenders et al. 2014). When a patient presents with an apparently solitary PPGL, the opportunity to diagnose an underlying hereditary basis is supported by positive implications for that patient (early detection of metachronous disease and/or associated tumours) and their family members, but counterbalanced by variable penetrance and the need for lifelong screening. This is particularly true for SDHA (PGL5) and SDHC (PGL3), for which penetrance appears to be much lower than for SDHB (PGL4) and SDHD (PGL1). In contrast, PCs are rarely the index event in other forms of hereditary PC because their syndromic features are more highly penetrant: MEN2 (associated with RET mutations) will almost always present with medullary thyroid cancer, Von Recklinhausen's disease (NF1) will be apparent from cutaneous stigmata of that disease and a diagnosis of VHL syndrome is known in about $50-70 \%$ cases before PPGLs develop (Opocher et al. 2005).

The approach to genetic testing is therefore moderated by several factors, including age at presentation, location of tumour, malignant disease, presence of syndromic features and/or multifocal disease, pattern of circulating catecholamines and immunohistochemistry of tumour.

Consistent with autosomal dominant pattern of inheritance, each child of an individual with a hereditary PGL syndrome has a $50 \%$ chance of inheriting the pathogenic variant. Parent-of-origin effects on disease expression for SDHD and SDHAF2 have been described above, such that children inheriting these mutations from their mother have negligible risk of developing the disease.

Preimplantation genetic diagnosis is an option that some $S D H x$ carriers will wish to consider, although careful counseling about its merits is always required.

\section{Clinical management}

The following general principles are advocated in managing patients with hereditary PPGL syndromes (Lenders et al. 2014):

i) diagnosis is based on clinical suspicion, followed by confirmatory biochemistry (elevated plasma normetanephrine in the case of TAPGL or PC) and imaging (CT or MRI);

ii) if hereditary PGL is known or strongly suspected in a patient presenting with an index tumour, then imaging from neck to pelvis should be performed to exclude synchronous lesions; ${ }^{68} \mathrm{Ga}$-DOTATATE PET imaging may be appropriate in this regard;

iii) definitive treatments should be planned and performed at expert centres;

Published by Bioscientifica Ltd. 
iv) for catecholamine-secreting tumours (TAPGLs, PCs and some HNPGLs) surgery is appropriate but only after pre-operative treatment with an $\alpha$-blocker (e.g. phenoxybenzamine or doxazosin);

v) treatment options for non-secreting HNPGLs include surgery, radiosurgery, radiofrequency ablation or cryoablation (Taïeb et al. 2014);

vi) histopathology should include careful assessment of SDHB and SDHA immunohistochemistry;

vii) negative SDHB immunohistochemistry should prompt consideration of genetic testing for mutations in SDHA, SDHB, SDHC or SDHD after appropriate genetic counseling; negative SDHA immunohistochemistry should prompt consideration of genetic testing for mutations in SDHA;

viii) genetic testing is performed on DNA extracted from peripheral blood leucoytes and should include validated methods for detecting point mutations, insertions and deletions as well as large deletions in SDHx genes;

ix) a positive result from genetic testing should lead to cascade testing of first-degree relatives after appropriate counseling and

$\mathrm{x})$ individuals discovered to carry a pathogenic mutation in SDHx genes should undergo lifelong biochemical and clinical surveillance for PPGLs. For PGL1 and PGL4, imaging from neck to pelvis (e.g. with MRI) every 2-3 years is recommended to detect PPGLs, renal cell cancers and GISTs.

\section{Conclusions}

Elucidating the genetic basis of the hereditary paraganglioma syndromes has stimulated great advances in clinical care for these patients, providing opportunities for early detection and treatment of component tumours, but not without costs: both in terms of resources required for genetic testing and then lifetime screening of $S D H x$ mutation carriers to detect tumour development anywhere from base of skull to pelvis; and also from the psychological burden these patients bear from not knowing if, when, where and in what manner (benign or malignant) these tumours will develop. Further research is needed to clarify if certain genotypes more reliably predict phenotypic behavior, or if environmental and/or genetic modifiers can be incorporated into risk algorithms. There is also an urgent need to develop better therapies for metastatic paragangliomas; and in these, SDH deficiency may yet prove to be an Achilles heel susceptible to synthetically lethal treatments.

\section{Footnote}

This paper is part of a thematic review section on 15th Anniversary of Paraganglioma and Pheochromocytoma. The Guest Editors for this section were Wouter de Herder and Hartmut Neumann.

\section{Declaration of interest}

The authors declare that there is no conflict of interest that could be perceived as prejudicing the impartiality of this review.

\section{Funding}

This work was supported by the Hillcrest Foundation and the Pheo Para Alliance.

\section{Acknowledgements}

We thank Dr Trish Dwight and Mr Edward Kim for careful review of the figures. We also thank Dr Venessa Tsang and Prof. Anthony Gill for many productive discussions on the topics discussed herein

\section{References}

Amar L \& Eisenhofer G 2015 Diagnosing phaeochromocytoma/paraganglioma in a patient presenting with critical illness: biochemistry versus imaging. Clinical Endocrinology [in press]. (doi:10.1111/cen.12745)

Amar L, Servais A, Gimenez-Roqueplo A-P, Zinzindohoue F, Chatellier G \& Plouin PF 2005 Year of diagnosis, features at presentation, and risk of recurrence in patients with pheochromocytoma or secreting paraganglioma. Journal of Clinical Endocrinology and Metabolism 90 2110-2116. (doi:10.1210/jc.2004-1398)

Amar L, Baudin E, Burnichon N, Peyrard S, Silvera S, Bertherat J, Bertagna X, Schlumberger M, Jeunemaitre X \& Gimenez-Roqueplo AP 2007 Succinate dehydrogenase $\mathrm{B}$ gene mutations predict survival in patients with malignant pheochromocytomas or paragangliomas. Journal of Clinical Endocrinology and Metabolism 92 3822-3828. (doi:10.1210/jc.2007-0709) Astrom K, Cohen JE, Willett-Brozick JE, Aston CE \& Baysal BE 2003 Altitude is a phenotypic modifier in hereditary paraganglioma type 1: evidence for an oxygen sensing defect. Human Genetics 113 228-237. (doi:10.1007/s00439-003-0969-6)

Astuti D, Douglas F, Lennard TW, Aligianis IA, Woodward ER, Evans DG, Eng C, Latif F \& Maher ER 2001a Germline SDHD mutation in familial pheochromocytoma. Lancet 357 1181-1182. (doi:10.1016/S01406736(00)04378-6)

Astuti D, Latif F, Dallol A, Dahia PL, Douglas F, George E, Skoldberg F, Husebye ES, Eng C \& Maher ER $2001 b$ Gene mutations in the succinate dehydrogenase subunit SDHB cause susceptibility to familial pheochromocytoma and to familial paraganglioma. American Journal of Human Genetics 69 49-54. (doi:10.1086/321282)

van Baars F, Cremers C, van den Broek P, Geerts S \& Veldman J 1982 Genetic aspects of nonchromaffin paraganglioma. Human Genetics 60 305. (doi:10.1007/BF00569208)

Bayley JP, Devilee P \& Taschner PE 2005 The SDH mutation database: an online resource for succinate dehydrogenase sequence variants involved in pheochromocytoma, paraganglioma and mitochondrial complex II deficiency. BMC Medical Genetics 639.

Baysal BE, Ferrell RE, Willett-Brozick JE, Lawrence EC, Myssiorek D, Bosch A, van der Mey A, Taschner PE, Rubinstein WS, Myers EN et al. 2000 Mutations in SDHD, a mitochondrial complex II gene, in hereditary paraganglioma. Science 287 848-851. (doi:10.1126/science.287.5454.848)

Published by Bioscientifica Ltd. 
Baysal BE, Willett-Brozick JE, Lawrence EC, Drovdlic CM, Savul SA, McLeod DR, Yee HA, Brackmann DE, Slattery WH III, Myers EN et al. 2002 Prevalence of SDHB, SDHC, and SDHD germline mutations in clinic patients with head and neck paragangliomas. Journal of Medical Genetics 39 178-183. (doi:10.1136/jmg.39.3.178)

Beilan JA, Lawton A, Hajdenberg J \& Rosser CJ 2013 Pheochromocytoma of the urinary bladder: a systematic review of the comtemporary literature. BMC Urology 13 22. (doi:10.1186/1471-2490-13-22)

Benn DE, Croxson MS, Tucker K, Bamach CP, Richardson AL, Delbridge L, Pullan PT, Hammond J, Marsh DJ \& Roblinson BG 2003 Novel succinate dehydrogenasesubunit B (SDHB) mutations in familial phaeochromocytomas and paragangliomas, but an absence of somatic SDHB mutations in sporadicphaeochromocytomas. Oncogene 22 1358-1364. (doi:10.1038/sj.onc.1206300)

Benn DE, Gimenez-Roqueplo AP, Reilly JR, Bertherat J, Burgess J, Byth K, Croxson M, Dahia PL, Elston M, Gimm O et al. 2006 Clinical presentation and penetrance of pheochromocytoma/paraganglioma syndromes. Journal of Clinical Endocrinology and Metabolism 91 827-836. (doi:10.1210/jc.2005-1862)

Bhatia KS, Ismail MM, Sahdev A, Rockall AG, Hogarth K, Canizales A, Avril N, Monson JP, Grossman AB \& Reznek RH $2008{ }^{123}$ I-metaiodobenzylguanidine (MIBG) scintigraphy for the detection of adrenal and extraadrenal phaeochromocytomas: CT and MRI correlation. Clinical Endocrinology 69 181-188. (doi:10.1111/j.1365-2265.2008.03256.x)

Bourgeron T, Rustin P, Chretien D, Birch-Machin M, Bourgeois M, Viegas-Pequignot E, Munnich A \& Rotig A 1995 Mutation of a nuclear succinate dehydrogenase gene results in mitochondrial respiratory chain deficiency. Nature Genetics 11 144-149. (doi:10.1038/ng1095-144)

Brouwers FM, Eisenhofer G, Tao JJ, Kant JA, Adams KT, Linehan WM \& Pacak K 2006 High frequency of SDHB germline mutations in patients with malignant catecholamine-producing paragangliomas: implications for genetic testing. Journal of Clinical Endocrinology and Metabolism 91 4505-4509. (doi:10.1210/jc.2006-0423)

Burnichon N, Rohmer V, Amar L, Herman P, Leboulleux S, Darrouzet V, Niccoli P, Gaillard D, Chabrier G, Chabolle F et al. 2009 The succinate dehydrogenase genetic testing in a large prospective series of patients with paragangliomas. Journal of Clinical Endocrinology and Metabolism 94 2817-2827. (doi:10.1210/jc.2008-2504)

Burnichon N, Brière JJ, Libé R, Vescovo L, Rivière J, Tissier F, Jouanno E, Jeunemaitre X, Bénit P, Tzagoloff A et al. 2010 SDHA is a tumor suppressor gene causing paraganglioma. Human Molecular Genetics 19 3011-3020. (doi:10.1093/hmg/ddq206)

Cascón A, Montero-Conde C, Ruiz-Llorente S, Mercadillo F, Leton R, Rodrıguez-Antona C, Martınez-Delgado B, Delgado M, Diez A, Rovira A et al. 2006 Gross SDHB deletions in patients with paraganglioma detected by multiplex PCR: a possible hot spot? Genes, Chromosomes \& Cancer 45 213-219.

Cascón A, Landa I, Lopez-Jimenez E, Diez-Hernandez A, Buchta M, MonteroConde C, Leskela S, Leandro-Garcia LJ, Leton R, Rodriguez-Antona C et al. 2008 Molecular characterisation of a common SDHB deletion in paraganglioma patients. Journal of Medical Genetics 45 233-238.

Cascón A, Pita G, Burnichon N, Landa I, López-Jiménez E, Montero-Conde C, Leskelä S, Leandro-García LJ, Letón R, Rodríguez-Antona C et al. 2009 Genetics of pheochromocytoma and paraganglioma in Spanish patients. Journal of Clinical Endocrinology and Metabolism 94 1701-1705.

Chase WH 1933 Familial and bilateral tumors of the carotid body. Journal of Pathology and Bacteriology 36 1-12. (doi:10.1002/path.1700360102)

Corless CL, Barnett CM \& Heinrich MC 2011 Gastrointestinal stromal tumours: origin and molecular oncology. Nature Reviews. Cancer 11 865-878.

Dahia PL, Ross KN, Wright ME, Hayashida CY, Santagata S, Barontini M, Kung AL, Sanso G, Powers JF, Tischler AS et al. 2005 A HIF1 $\alpha$ regulatory loop links hypoxia and mitochondrial signals in pheochromocytomas. PLoS Genetics 25 72-80.

van Duinen N, Steenvoorden D, Kema IP, Jansen JC, Vriends AH, Bayley JP, Smit JW, Romijn JA \& Corssmit EP 2010 Increased urinary excretion of 3-methoxytyramine in patients with head and neck paragangliomas.
Journal of Clinical Endocrinology and Metabolism 95 209-214. (doi:10.1210/jc.2009-1632)

Dwight T, Benn DE, Clarkson A, Vilain R, Lipton L, Robinson BG, CliftonBligh RJ \& Gill AJ 2013a Loss of SDHA expression identifies SDHA mutations in succinate dehydrogenase-deficient gastrointestinal stromal tumors. American Journal of Surgical Pathology 37 226-233. (doi:10.1097/PAS.0b013e3182671155)

Dwight T, Mann K, Benn DE, Robinson BG, McKelvie P, Gill AJ, Winship I \& Clifton-Bligh RJ 2013b Familial SDHA mutation associated with pituitary adenoma and pheochromocytoma/paraganglioma. Journal of Clinical Endocrinology and Metabolism 98 E1103-E1108. (doi:10.1210/jc. 2013-1400)

Eisenhofer G, Lenders JW, Siegert G, Bornstein SR, Friberg P, Milosevic D, Mannelli M, Linehan WM, Adams K, Timmers HJ et al. 2012 Plasma methoxytyramine: a novel biomarker of metastatic pheochromocytoma and paraganglioma in relation to established risk factors of tumour size, location and SDHB mutation status. European Journal of Cancer 48 1739-1749. (doi:10.1016/j.ejca.2011.07.016)

Evenepoel L, Papathomas TG, Krol N, Korpershoek E, de Krijger RR, Persu A $\&$ Dinjens WN 2014 Toward an improved definition of the genetic and tumor spectrum associated with SDH germ-line mutations. Genetics in Medicine [in press]. (doi:10.1038/gim.2014.162)

Gill AJ, Chou A, Vilain R, Clarkson A, Lui M, Jin R, Tobias V, Samra J, Goldstein D, Smith C et al. 2010a Immunohistochemistry for SDHB divides gastrointestinal stromal tumors (GISTs) into 2 distinct types. American Journal of Surgical Pathology 34 636-644.

Gill AJ, Benn DE, Chou A, Clarkson A, Muljono A, Meyer-Rochow GY, Richardson AL, Sidhu SB, Robinson BG \& Clifton-Bligh RJ $2010 b$ Immunohistochemistry for SDHB triages genetic testing of SDHB, SDHC and SDHD in paraganglioma-pheochromocytoma. Human Pathology 41 805-814. (doi:10.1016/j.humpath.2009.12.005)

Gill AJ, Pachter NS, Clarkson A, Tucker KM, Winship IM, Benn DE, Robinson BG \& Clifton-Bligh RJ 2011 Renal tumours and hereditary pheochromocytoma-paraganglioma syndrome type 4. New England Journal of Medicine 364 885-886. (doi:10.1056/NEJMc1012357)

Gill AJ, Lipton L, Taylor J, Benn DE, Richardson AL, Frydenberg M, Shapiro J, Clifton-Bligh RJ, Chow CW \& Bogwitz M 2013 Germline SDHC mutation presenting as recurrent SDH deficient GIST and renal carcinoma. Pathology 45 689-691. (doi:10.1097/PAT. 0000000000000018)

Gill AJ, Hes O, Papathomas T, Šedivcová M, Tan PH, Agaimy A, Andresen PA, Kedziora A, Clarkson A, Toon CW et al. 2014a Succinate dehydrogenase (SDH)-deficient renal carcinoma: a morphologically distinct entity: a clinicopathologic series of 36 tumours from 27 patients. American Journal of Surgical Pathology 38 1588-1602. (doi:10.1097/PAS.0000000000000292)

Gill AJ, Toon CW, Clarkson A, Sioson L, Chou A, Winship I, Robinson B, Benn DE, Clifton-Bligh RJ \& Dwight T 2014b Succinate dehydrogenase deficiency is rare in pituitary adenomas. American Journal of Surgical Pathology 38 560-566. (doi:10.1097/PAS.0000000000000149)

Gimenez-Roqueplo AP, Favier J, Rustin P, Mourad JJ, Plouin PF, Corvol P, Rotig A \& Jeunemaitre X 2001 The R22X mutation of the SDHD gene in hereditaryparaganglioma abolishes the enzymatic activity of complex II in the mitochondrial respiratory chain and activates the hypoxia pathway. American Journal of Human Genetics 69 1186-1197. (doi:10.1086/324413)

Gimenez-Roqueplo AP, Favier J, Rustin P, Rieubland C, Crespin M, Nau V, Khau VanKien P, Corvol P, Plouin PF, Jeunemaitre X et al. 2003 Mutations in the SDHB gene are associated with extra-adrenal and/or malignant pheochromocytomas. Cancer Research 63 5615-5621.

Gimenez-Roqueplo AP, Dahia PL \& Robledo M 2012 Update in the genetics of paraganglioma and pheochromocytoma and hereditary syndromes. Hormone and Metabolic Research 44 328-333. (doi:10.1055/s-00311301302)

Gimenez-Roqueplo AP, Caumont-Prim A, Houzard C, Hignette C, Hernigou A, Halimi P, Niccoli P, Leboulleux S, Amar L, Borson-Chazot F 
et al. 2013 Imaging work-up for screening of paraganglioma and pheochromocytoma in SDHx mutation carriers: a multicenter prospective study from the PGL:EVA Investigators. Journal of Clinical Endocrinology and Metabolism 98 E162-E173. (doi:10.1210/jc.2012-2975)

Gimm O, Armanios M, Dziema H, Neumann HP \& Eng C 2000 Somatic and occult germ-line mutations in SDHD, a mitochondrial complex II gene, in nonfamilial pheochromocytoma. Cancer Research 60 6822-6825.

Haller F, Moskalev EA, Faucz FR, Barthelmeß S, Wiemann S, Bieg M, Assie G, Bertherat J, Schaefer IM, Otto C et al. 2014 Aberrant DNA hypermethylation of SDHC: a novel mechanism of tumor development in Carney triad. Endocrine-Related Cancer 21 567-577. (doi:10.1530/ERC-14-0254)

Hao HX, Khalimonchuk O, Schraders M, Dephoure N, Bayley JP, Kunst H, Devilee P, Cremers CW, Schiffman JD, Bentz BG et al. 2009 SDH5, a gene required for flavination of succinate dehydrogenase, is mutated in paraganglioma. Science 325 1139-1142. (doi:10.1126/science.1175689)

Hoegerle S, Nitzsche E, Altehoefer C, Ghanem N, Manz T, Brink I, Reincke M, Moser E \& Neumann HP 2002 Pheochromocytomas: detection with ${ }^{18} \mathrm{~F}$ DOPA whole-body PET - initial results. Radiology 222 507-512. (doi:10.1148/radiol.2222010622)

Jacques AE, Sahdev A, Sandrasagara M, Goldstein R, Berney D, Rockall AG, Chew S \& Reznek RH 2008 Adrenal phaeochromocytoma: correlation of MRI appearances with histology and function. European Journal of Radiology 18 2885-2892. (doi:10.1007/s00330-008-1073-z)

Janeway KA, Kim SY, Lodish M, Nose V, Rustin P, Gaal J, Dahia PL, Liegl B, Ball ER, Raygada M et al. 2011 Defects in succinate dehydrogenase in gastrointestinal stromal tumors lacking KIT and PDGFRA mutations. PNAS 108 314-318. (doi:10.1073/pnas.1009199108)

Janssen I, Blanchet EM, Adams K, Chen CC, Millo C, Herscovitch P, Taieb D, Kebebew E, Lehnert H, Fojo AT et al. 2015 Superiority of [68Ga]DOTATATE PET/CT to other functional imaging modalities in the localization of SDHB-associated metastatic pheochromocytoma and paraganglioma. Clinical Cancer Research [in press]. (doi:10.1158/10780432.CCR-14-2751)

Jensen JC, Choyke PL, Rosenfeld M, Pass HI, Keiser H, White B, Travis W \& Linehan WM 1991 A report of familial carotid body tumors and multiple extra-adrenal pheochromocytoma. Journal of Urology 145 1040-1042.

Killian JK, Miettinen M, Walker RL, Wang Y, Zhu YJ, Waterfall JJ, Noyes N, Retnakumar P, Yang Z, Smith WI Jr et al. 2014 Recurrent epimutation of SDHC in gastrointestinal stromal tumors. Science Translational Medicine 6 268ra177. (doi:10.1126/scitranslmed.3009961)

Kopetschke R, Slisko M, Kilisli A, Tuschy U, Wallaschofski H, Fassnacht M, Ventz M, Beuschlein F, Reincke M, Reisch N et al. 2009 Frequent incidental discovery of phaeochromocytoma: data from a German cohort of 201 phaeochromocytoma. European Journal of Endocrinology 161 355-361. (doi:10.1530/EJE-09-0384)

Korpershoek E, Favier J, Gaal J, Burnichon N, van Gessel B, Oudijk L, Badoual C, Gadessaud N, Venisse A, Bayley JP et al. 2011 SDHA immunohistochemistry detects germline SDHA gene mutatons in apparently sporadic paragangliomas and pheochromocytomas. Journal of Clinical Endocrinology and Metabolism 96 E1472-E1476. (doi:10.1210/jc.2011-1043)

Kunst HP, Rutten MH, de Mönnink JP, Hoefsloot LH, Timmers HJ, Marres HA, Jansen JC, Kremer H, Bayley JP \& Cremers CW 2011 SDHAF2 (PGL2-SDH5) and hereditary head and neck paraganglioma. Clinical Cancer Research 17 247-254. (doi:10.1158/1078-0432.CCR-10-0420)

Lenders JW, Duh QY, Eisenhofer G, Gimenez-Roqueplo AP, Grebe SK, Murad MH, Naruse M, Pacak K, Young WF Jr \& Endocrine Society 2014 Pheochromocytoma and paraganglioma: an Endocrine Society clinical practice guideline. Journal of Clinical Endocrinology and Metabolism 99 1915-1942. (doi:10.1210/jc.2014-1498)

Lopez-Jimenez E, de Campos JM, Kusak EM, Landa I, Leskela S, Montero-Conde C, Leandro-Garcia LJ, Vallejo LA, Madrigal B, Rodriguez-Antona C et al. 2008 SDHC mutation in an elderly patient without familial antecedents. Clinical Endocrinology 69 906-910. (doi:10.1111/j.1365-2265.2008.03368.x)
Mannelli M, Ianni L, Cilotti A \& Conti A 1999 Pheochromocytoma in Italy: a multicentric retrospective study. European Journal of Endocrinology $\mathbf{1 4 1}$ 619-624. (doi:10.1530/eje.0.1410619)

Mannelli M, Ercolino T, Giachè V, Simi L, Cirami C \& Parenti G 2007 Genetic screening for pheochromocytoma: should SDHC gene analysis be included? Journal of Medical Genetics 44 586-587. (doi:10.1136/jmg. 2007.051045)

Mannelli M, Castellano M, Schiavi F, Filetti S, Giacche‘ M, Mori L, Pignataro V, Bernini G, Giache‘ V, Bacca A et al. 2009 Clinically guided genetic screening in a large cohort of Italian patients with pheochromocytomas and/or functional or nonfunctional paragangliomas. Journal of Clinical Endocrinology and Metabolism 94 1541-1547. (doi:10.1210/jc.2008-2419)

Maurice JB, Troke R, Win Z, Ramachandran R, Al-Nahhas A, Naji M, Dhillo W, Meeran K, Goldstone AP, Martin NM et al. 2012 A comparison of the performance of ${ }^{68} \mathrm{Ga}$-DOTATATE PET/CT and ${ }^{123}$ I-MIBG SPECT in the diagnosis and follow-up of phaeochromocytoma and paraganglioma. European Journal of Nuclear Medicine and Molecular Imaging 39 1266-1270. (doi:10.1007/s00259-012-2119-7)

McWhinney SR, Pilarski RT, Forrester SR, Schneider MC, Sarquis MM, Dias EP \& Eng C 2004 Large germline deletions of mitochondrial complex II subunits SDHB and SDHD in hereditary paraganglioma. Journal of Clinical Endocrinology and Metabolism 89 5694-5699. (doi:10.1210/jc.2004-0769)

Muller U, Troidl C \& Niemann S 2005 SDHC mutations in hereditary paraganglioma/pheochromocytoma. Familial Cancer 4 9-12. (doi:10.1007/s10689-004-0621-1)

van Nederveen FH, Gaal J, Favier J, Korpershoek E, Oldenburg RA, de Bruyn EM, Sleddens HF, Derkx P, Rivière J, Dannenberg H et al. 2009 An immunohistochemical procedure to detect patients with paraganglioma and phaeochromocytoma with germline SDHB, SDHC or SDHD gene mutations: a retrospective and prospective analysis. Lancet. Oncology 8 764-771. (doi:10.1016/S1470-2045(09)70164-0)

Neumann HP \& Erlic Z 2008 Maternal transmission of symptomatic disease with SDHD mutation: fact or fiction? Journal of Clinical Endocrinology and Metabolism 93 1573-1575. (doi:10.1210/jc.2008-0569)

Neumann HP, Bausch B, McWhinney SR, Bender BU, Gimm O, Franke G, Schipper J, Klisch J, Altehoefer C, Zerres K et al. 2002 Germ-line mutations in nonsyndromic pheochromocytoma. New England Journal of Medicine 346 1459-1466. (doi:10.1056/NEJMoa020152)

Neumann HP, Pawlu C, Peczkowska M, Bausch B, McWhinney SR, Muresan M, Buchta M, Franke G, Klisch J, Bley TA et al. 2004 Distinct clinical features of paraganglioma syndromes associated with SDHB and SDHD gene mutations. Journal of the American Medical Association 292 943-951. (doi:10.1001/jama.292.8.943)

Niemann S \& Muller U 2000 Mutations in SDHC cause autosomal dominant paraganglioma, type 3. Nature Genetics 26 268-270. (doi:10. 1038/81551)

Niemann S, Muller U, Engelhardt D \& Lohse P 2003 Autosomal dominant malignant and catecholamine-producing paraganglioma caused by a splice donor site mutation in SDHC. Human Genetics 113 92-94.

Opocher G, Conton P, Schiavi F, Macino B \& Mantero F 2005 Phaeochromocytoma in von Hippel-Lindau disease and neurofibromatosis type 1 . Familial Cancer 4 13-16. (doi:10.1007/s10689-004-6128-y)

Pacak K, Eisenhofer G, Carrasquillo JA, Chen CC, Li ST \& Goldstein DS 2001 6-[18F]fluorodopamine positron emission tomographic (PET) scanning for diagnostic localization of pheochromocytoma. Hypertension 38 6-8. (doi:10.1161/01.HYP.38.1.6)

Paik JY, Toon CW, Benn DE, High H, Hasovitz C, Pavlakis N, Clifton-Bligh RJ \& Gill AJ 2014 Renal carcinoma associated with succinate dehydrogenase B mutation: a new and unique subtype of renal carcinoma. Journal of Clinical Oncology 32 e10-e13. (doi:10.1200/JCO.2012.47.2647)

Pantaleo MA, Astolfi A, Indio V, Moore R, Thiessen N, Heinrich MC, Gnocchi C, Santini D, Catena F, Formica S et al. 2011a SDHA lossof-function mutations in KIT-PDGFRA wild-type gastrointestinal stromal tumors identified by massively parallel sequencing. Journal of the National Cancer Institute 103 983-987. (doi:10.1093/jnci/djr130) 
Pantaleo MA, Nannini M, Astolfi A \& Biasco G 2011b A distinct pediatrictype gastrointestinal stromal tumor in adults: potential role of succinate dehydrogenase subunit A mutations. American Journal of Surgical Pathology 35 1750-1752. (doi:10.1097/PAS.0b013e318230a523)

Papathomas TG, Gaal J, Corssmit EP, Oudijk L, Korpershoek E, Heimdal K, Bayley JP, Morreau H, van Dooren M, Papaspyrou K et al. 2013 Nonpheochromocytoma (PCC)/paraganglioma (PGL) tumors in patients with succinate dehydrogenase-related PCC-PGL syndromes: a clinicopathological and molecular analysis. European Journal of Endocrinology 170 1-12. (doi:10.1530/EJE-13-0623)

Papathomas TG, Oudijk L, Persu A, Gill AJ, van Nederveen F, Tischler AS Tissier F, Volante M, Matias-Guiu X, Smid M et al. 2015 SDHB/SDHA immunohistochemistry in pheochromocytomas and paragangliomas: a multicenter interobserver variation analysis using virtual microscopy: a Multinational Study of the European Network for the Study of Adrenal Tumors (ENS@T). Modern Pathology 28 807-821. (doi:10.1038/ modpathol.2015.41)

Pasini B, McWhinney SR, Bei T, Matyakhina L, Stergiopoulos S, Muchow M, Boikos SA, Ferrando B, Pacak K, Assie G et al. 2008 Clinical and molecular genetics of patients with the Carney-Stratakis syndrome and germline mutations of the genes coding for the succinate dehydrogenase subunits SDHB, SDHC, and SDHD. European Journal of Human Genetics 16 79-88. (doi:10.1038/sj.ejhg.5201904)

Peczkowska M, Cascon A, Prejbisz A, Kubaszek A, Cwikła BJ, Furmanek M, Erlic Z, Eng C, Januszewicz A \& Neumann HP 2008 Extra-adrenal and adrenal pheochromocytomas associated with a germline SDHC mutation. Nature Clinical Practice. Endocrinology \& Metabolism 4 111-115. (doi:10.1038/ncpendmet0726)

Pigny P, Vincent A, Cardot Bauters C, Bertrand M, de Montpreville VT, Crepin M, Porchet N \& Caron P 2008 Paraganglioma after maternal transmission of a succinate dehydrogenase gene mutation. Journal of Clinical Endocrinology and Metabolism 93 1609-1615. (doi:10.1210/jc.2007-1989)

Plouin PF, Degoulet P, Tugayé A, Ducrocq MB \& Ménard J 1981 Screening for phaeochromocytoma: in which hypertensive patients? A semiological study of 2585 patients, including 11 with phaeochromocytoma $\mathrm{La}$ Nouvelle Presse Médicale 10 869-872.

Pritchett JW 1982 Familial occurrence of carotid body tumor and pheochromocytoma. Cancer 49 2578-2579. (doi:10.1002/10970142(19820615)49:12<2578::AID-CNCR2820491227>3.0.CO;2-M)

Ricketts C, Woodward ER, Killick P, Morris MR, Astuti D, Latif F \& Maher ER 2008 Germline SDHB mutations and familial renal cell carcinoma. Journal of the National Cancer Institute 100 1260-1262. (doi:10.1093/jnci/djn254)

Ricketts CJ, Forman JR, Rattenberry E, Bradshaw N, Lalloo F, Izatt L, Cole TR, Armstrong R, Kumar VK, Morrison PJ et al. 2010 Tumor risks and genotype-phenotype-proteotype analysis in 358 patients with germline mutations in SDHB and SDHD. Human Mutation 31 41-51. (doi:10.1002/ humu.21136)

Schiavi F, Boedeker CC, Bausch B, Peczkowska M, Gomez CF, Strassburg T, Pawlu C, Buchta M, Salzmann M, Hoffmann MM et al. 2005 Predictors and prevalence of paraganglioma syndrome associated with mutations of the SDHC gene. Journal of the American Medical Association 294 2057-2063. (doi:10.1001/jama.294.16.2057)

Schiavi F, Milne RL, Anda E, Blay P, Castellano M, Opocher G, Robledo M \& Cascón A 2010 Are we over-estimating the penetrance of mutations in SDHB? Human Mutation 31 761-762. (doi:10.1002/humu.21269)

Selak MA, Armour SM, MacKenzie ED, Boulahbel H, Watson DG, Mansfield KD, Pan Y, Simon MC, Thompson CB \& Gottlieb E 2005 Succinate links TCA cycle dysfunction to oncogenesis by inhibiting HIF- $\alpha$ prolyl hydroxylase. Cancer Cell 7 77-85. (doi:10.1016/j.ccr.2004.11.022)
Shen WT, Grogan R, Vriens M, Clark OH \& Duh QY 2010 One hundred two patients with pheochromocytoma treated at a single institution since the introduction of laparoscopic adrenalectomy. Archives of Surgery $\mathbf{1 4 5}$ 893-897. (doi:10.1001/archsurg.2010.159)

Suárez C, Rodrigo JP, Bödeker CC, Llorente JL, Silver CE, Jansen JC, Takes RP, Strojan P, Pellitteri PK, Rinaldo A et al. 2013 Jugular and vagal paragangliomas: systematic study of management with surgery and radiotherapy. Head \& Neck 35 1195-1204.

Taïeb D, Kaliski A, Boedeker CC, Martucci V, Fojo T, Adler JR Jr \& Pacak K 2014 Current approaches and recent developments in the management of head and neck paraganglioma. Endocrine Reviews 35 795-819.

Taschner PE, Jansen JC, Baysal BE, Bosch A, Rosenberg EH, Brocker-Vriends AH, vanDer Mey AG, van Ommen GJ, Cornelisse CJ \& Devilee P 2001 Nearly all hereditary paragangliomas in the Netherlands are caused by two founder mutations in the SDHD gene. Genes, Chromosomes \& Cancer 31 274-281. (doi:10.1002/gcc.1144)

Timmers HJ, Kozupa A, Eisenhofer G, Raygada M, Adams KT, Solis D, Lenders JW \& Pacak K 2007 Clinical presentations, biochemical phenotypes, and genotype-phenotype correlations in patients with succinate dehydrogenase subunit B-associated pheochromocytomas and paragangliomas. Journal of Clinical Endocrinology and Metabolism 92 779-786. (doi:10.1210/jc.2006-2315)

Timmers HJ, Chen CC, Carrasquillo JA, Whatley M, Ling A, Havekes B, Eisenhofer G, Martiniova L, Adams KT \& Pacak K 2009 Comparison of ${ }^{18} \mathrm{~F}$-fluoro-L-DOPA, ${ }^{18} \mathrm{~F}$-fluoro-deoxyglucose, and ${ }^{18} \mathrm{~F}$-fluorodopamine PET and ${ }^{123}$ I-MIBG scintigraphy in the localization of pheochromocytoma and paraganglioma. Journal of Clinical Endocrinology and Metabolism 94 4757-4767. (doi:10.1210/jc.2009-1248)

Vanharanta S, Buchta M, McWhinney SR, Virta SK, Pec-zkowska M, Morrison CD, Lehtonen R, Januszewicz A, Järvinen H, Juhola M et al. 2004 Early-onset renal cell carcinoma as a novel extra-paraganglial component of SDHB-associated heritable paraganglioma. American Journal of Human Genetics 74 153-159. (doi:10.1086/381054)

Welander J, Söderkvist P \& Gimm O 2011 Genetics and clinical characteristics of hereditary pheochromocytomas and paragangliomas. Endocrine-Related Cancer 18 R253-R276. (doi:10.1530/ERC-11-0170)

Xekouki P \& Stratakis CA 2012 Succinate dehydrogenase (SDHx) mutation in pituitary tumors: could this be a new role for mitochondrial complex II and/or Krebs cycle defects? Endocrine-Related Cancer 19 C33-C40. (doi:10.1530/ERC-12-0118)

Xekouki P, Pacak K, Almeida M, Wassif CA, Rustin P, Nesterova M, de la Luz Sierra M, Matro J, Ball E, Azevedo M et al. 2012 Succinate dehydrogenase (SDH) D subunit (SDHD) inactivation in a growthhormone-producing pituitary tumor: a new association for SDH? Journal of Clinical Endocrinology and Metabolism 97 E357-E366. (doi:10. 1210/jc.2011-1179)

Xekouki P, Szarek E, Bullova P, Giubellino A, Quezado M, Mastroyannis SA, Mastorakos P, Wassif CA, Raygada M, Rentia N et al. 2015 Pituitary adenoma with paraganglioma/pheochromocytoma (3PAs) and succinate dehydrogenase defects in humans and mice. Journal of Clinical Endocrinology and Metabolism 100 E710-E719. (doi:10.1210/ jc.2014-4297)

Yeap PM, Tobias ES, Mavraki E, Fletcher A, Bradshaw N, Freel EM, Cooke A, Murday VA, Davidson HR, Perry CG et al. 2011 Molecular analysis of pheochromocytoma after maternal transmission of SDHD mutation elucidates mechanism of parent-of-origin effect. Journal of Clinical Endocrinology and Metabolism 96 E2009-E2013. (doi:10.1210/jc.2011-1244)

Young WF Jr 2006 Paragangliomas: clinical overview. Annals of the New York Academy of Sciences 1073 21-29. (doi:10.1196/annals.1353.002)

Received in final form 1 June 2015

Accepted 9 June 2015

Made available online as an Accepted Preprint

11 June 2015 http://erc.endocrinology-journals.org

DOI: $10.1530 /$ ERC-15-0268
(C) 2015 The authors Printed in Great Britain
Published by Bioscientifica Ltd. 